\title{
Promoting Restaurants Using Social Networks: Still A Lot Of Room For Improvement
}

José Vicente Sanchís Verdeguer, Universitat Politècnica de València, Spain Ángel Peiró-Signes, Universitat Politècnica de València, Spain María-del-Val Segarra-Oña, Universitat Politècnica de València, Spain

\begin{abstract}
A growing trend in the hospitality industry is the promotion of products and services on social networks as an effective and economical way to reach a very important population mass with a bidirectional speech.
\end{abstract}

The aim of this paper is to explore the processes used by Spanish restaurants in two ways: 1) adding to the portfolio of services offered and 2) for the recruitment of staff. Business models of social shopping can be divided largely into three categories: 1) social shopping intermediaries, 2) social shopping markets, and 3) social shopping search engines. It is observed that more and more Spanish restaurants use social shopping to attract their target audience, but this is not very long term. Therefore, a change in the Spanish restaurants' model is observed as the customer loyalty decreases and the online business increases. Understanding the key issues will be crucial in maintaining the competitiveness of the business of catering in Spain.

Keywords: Restaurants; Social Media; Facebook; Spain; Online Purchasing

\section{INTRODUCTION}

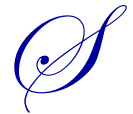

ocial media has become a major force in making consumer decisions, including areas such as the influence on decision-making, sharing information, forming opinions and attitudes, purchase, and evaluating experience after the purchase (Magnold and Faulds, 2009). In addition, social networks become important because they represent an innovative factor to add value to the services rendered and thus gain a competitive advantage which is subsequently used to provide better service to customers or to distance themselves from the competition.

Using social networks in services is a fast and inexpensive way to reach potential customers. Social shopping, the emergence of market intermediaries in the web 2.0, and the use of social networks for recruitment purposes are new business opportunities.

Spanish restaurants use social networks for various purposes, such as to promote their business in different ways and, to a lesser extent, to further aid in the process of recruitment (Dev, Winter and Mougeot Stroock, 2011; Kwok and Yu, 2013; Lee and Lee, 2012; Needles and Thompson, 2013).

Authors like Pantelidis (2010) and Lavidge and Steiner (1961) state that the major advantages of the use of social networks by restaurants are the low cost of using them, the reputation of the management, two-way dialogue, and the possibility of screening their target audience in promotional needs through social networks.

In this research, the authors have not observed any study about the advantages and disadvantages of using social networks in Spanish restaurants; therefore, further research on this topic is needed. 
Thus, the aim of this paper is to analyze, through a review of the literature, how social networks are used by Spanish restaurants and their advantages and disadvantages in three areas: 1) as a tool to promote their range of services, 2) to increase sales through brokers, and 3) as a complement to the process of recruitment and selection of staff.

\section{Advantages And Disadvantages Of Using Social Networks In Restaurants}

The social media marketing in restaurants requires a different approach to traditional marketing, as social media involves interacting directly with customers and public bi-directional. Many restaurants already use social media for a variety of purposes. Several authors have studied the advantages and disadvantages of using social networks in restaurants; the main contributions are presented in Table 1.

Table 1: Advantages And Disadvantages Of The Use Of Social Networks In Restaurants

\begin{tabular}{|c|c|}
\hline Advantages & Disadvantages \\
\hline $\begin{array}{l}\text { Clearly, the low cost of being active in one or more social } \\
\text { networks: For this reason, communication through social } \\
\text { networks mixes well with the cost structure of the restaurant } \\
\text { industry, which seeks to minimize the maximum fixed costs } \\
\text { and attempts to control variable costs (Pantelidis, 2010). }\end{array}$ & $\begin{array}{l}\text { 1) The bi-directionality is an advantage and may also become } \\
\text { a problem if the inputs received from customers become } \\
\text { critical or malicious actions (Lee and Jang, 2011). }\end{array}$ \\
\hline $\begin{array}{l}\text { 2) The ability to manage the reputation of the restaurant by a } \\
\text { friendly and close dialogue with potential customers: Most } \\
\text { important is the personal brand cache in the relationship or the } \\
\text { price of products or services in the hospitality industry. Being } \\
\text { able to directly influence the brand is an open door to } \\
\text { competitive advantage (Lavidge and Steiner, 1961). }\end{array}$ & $\begin{array}{l}\text { 2) The return on investment is one of the main drawbacks; not } \\
\text { the impossibility of investment returns, but the difficulty of } \\
\text { measuring such return. It is easy to quantify the cost of the use } \\
\text { of social networks, but quantifying how much benefit is } \\
\text { provided by a client recruited through a social network at a } \\
\text { given time is difficult and, especially, changes depending on } \\
\text { the time of year and the economic viability of the customer. }\end{array}$ \\
\hline $\begin{array}{l}\text { 3) Another advantage to consider is the bi-directionality of } \\
\text { social networks; i.e., social networks offer the ability to } \\
\text { deliver outputs to customers and receive inputs from them - a } \\
\text { phenomenon which supplies knowledge about direct changes } \\
\text { in the tastes of customers and gives the ability to evolve with } \\
\text { them (Lee and Jang, 2011). }\end{array}$ & \\
\hline $\begin{array}{l}\text { 4) The ability to choose the target audience is crucial for } \\
\text { promotions and the successful impact of business ideas. This } \\
\text { is as important as having a good product to sell and to sell it } \\
\text { well, as we know who we want to sell it to. Thus, social } \\
\text { networks are a useful tool because they allow us to reach a } \\
\text { good segmentation of the target audience (Needles and } \\
\text { Thompson, 2013). }\end{array}$ & \\
\hline
\end{tabular}

Source: Own elaboration

\section{Shopping In Social Networks As A New Business Model}

A business model is the framework for how an organization generates income and involves a series of planned activities or business processes to generate such activity (Lee and Lee, 2012).

Business models on the internet, or e-business models, have become important for the survival of companies in the global economy and are a fertile ground for innovation (Amit and Zott, 2001). Furthermore, ebusiness models must constantly evolve to adapt to the changing demands of its consumers. For example, Amazon.com was launched as an online bookstore in 1995; today it has evolved and offers the largest online store in the world and sells almost everything from books to beauty products (Lee and Lee, 2012). 
Following Lee and Lee, the business models of social shopping can be divided largely into three categories:

1. Agents of social shopping: companies that lead consumers to purchase products and services for traders together with a large discount in price; for example, Groupon, LivingSocial, and BuyWithMe.

2. Social shopping markets: companies that link buyers and sellers in one online platform and try to provide the optimal conditions for the promotion of transactions; for example, Google.

3. Search social shopping: those companies which display platforms looking for "intelligent" best deals and lists them on its website; for example, Yiplit.

According to Dholakia (2010), a professor at Rice University who conducted a study on Groupon and its effects, $66 \%$ of respondents considered that Groupon promotions were profitable. Finally, it was observed that $82 \%$ of the sample would be willing to buy another Groupon promotion in the future (see Figure 1).

\section{Diferencias entre rentabilidad y no rentabilidad de las promociones de Groupon.}

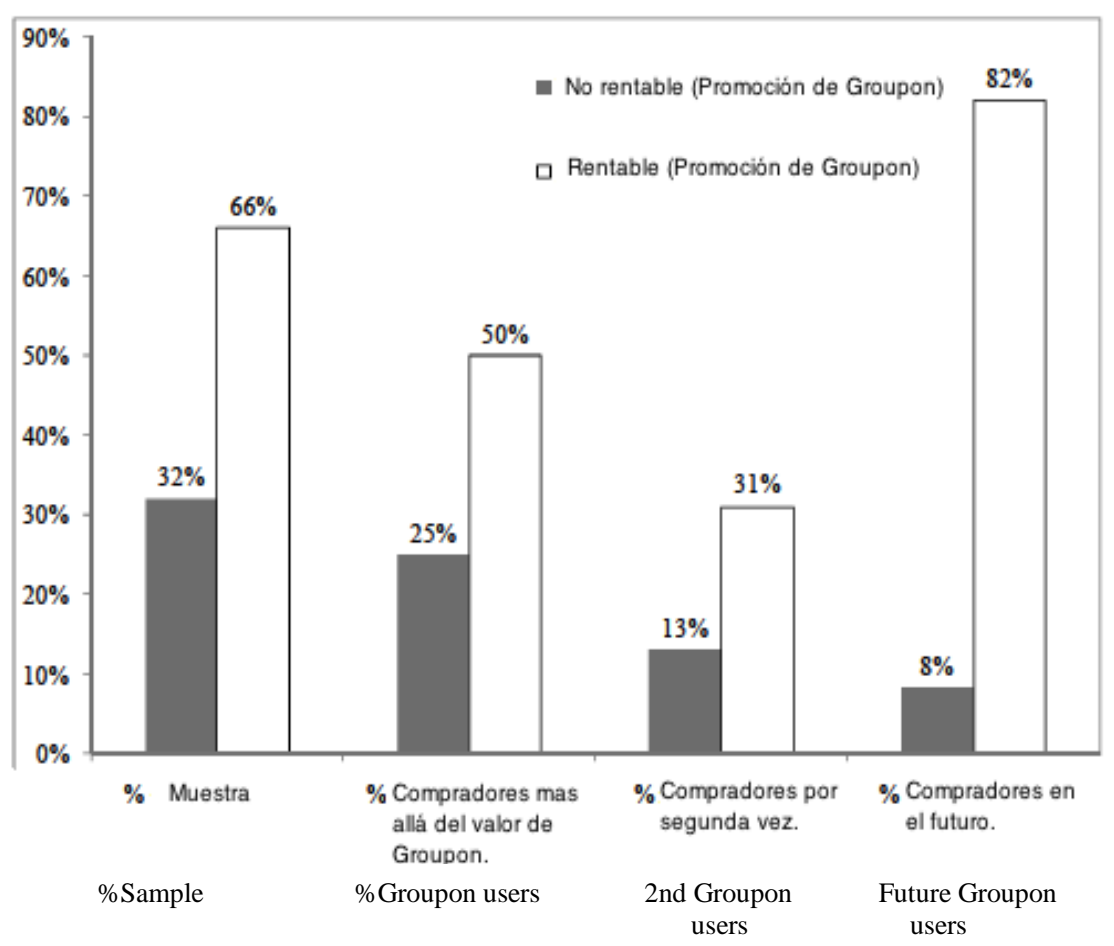

Source: Dholakia (2010)

Figure 1: Differences Between Profitability And Non-Profitability Of Groupon Promotions

\section{Disadvantages, Illustrations And Management Guidelines}

Following Lee and Lee (2012), the kind of problems that occur with the use of social purchases at restaurants are the following:

1. Some merchants may face significant losses.

2. An aggressive cross-selling often leads to dissatisfied customers.

3. Negative feedback from numerous customers can, over time, be the cause of a decrease in customers.

4. Some promotion expiration dates can be too long, making service scheduling difficult.

5. Social marketers must determine the optimal parameters of various variables of marketing promotions for each establishment. 


\section{CONCLUSION}

This study identified, through a literature review, the main uses of social media by restaurants; that is, to market their products and services, to increase sales, and to complement the human resources section.

First, the restaurants use social media to communicate with potential customers in a bi-directional way quickly, cheaply, and with the ability to offer a warm welcome to a target audience, which is identified as a significant advantage. In contrast, the possible disadvantages of a possible malicious action by a customer on the social network and the difficulty of measuring the return on investment in the management of social networks can be observed.

Next, the use of social networks by restaurants provides access to a new way of marketing their products, such as social shopping through discount bonds company - Groupon. The main problems highlighted are: 1) the possibility of facing uncontrolled margins with loss of benefits as a result of a poorly conceived discount scheme and 2) attempts to mitigate these losses with over sales can cause customer dissatisfaction and subsequent negative comments on social networks. Therefore, companies must determine the optimal parameters of a marketing plan regarding price and time as there is no economic benefit expected.

Third, restaurants use social networks to supplement the process of recruitment and selection of staff; i.e., use information from social networks to complement the profiles of candidates for certain work. Notably, the major source of value representing humans in business organizations, therefore, is an act of responsibility to use all information available to select workers. In this section, including social networks as a cheap and legitimate way to get first-hand information on potential candidates is a priority.

Finally, future research lines, such as the implementation of the social network - Twitter - in Spanish restaurants as brand enhancer, understanding consumer behavior through the use of social media in the hospitality industry, and the return arising from investment use of social networks in the hospitality industry, are recommended.

\section{ACKNOWLEDGMENTS}

The authors would like to thank Universitat Politècnica de València for its research funding to the Research Microcluster "Globalization, tourism and heritage: towards a sustainable development".

\section{AUTHOR INFORMATION}

José V. Sanchís-Verdeguer is a Ph.D. candidate at the doctoral program in Business Administration at Polytechnic University of Valencia and holds a Masters in Innovation and Business Development as well as a degree in Business Administration. He is the President of Rumisanver Cooperativa Valenciana, a restaurant association located in Valencia, Spain. E-mail: josevicentesanchis@gmail.com.

Angel Peiró-Signes has a Ph.D. in Business Administration and a Degree in Industrial Engineering. He is Assistant Professor in Analytical Accounting in Manufacturing firms and Strategic Management at the Universidad Politécnica de Valencia (Spain). His research interests include eco-innovation and economic performance of companies applied to industrial and service sectors. E-mail: anpeisig@omp.upv.es.

Maria-del-Val Segarra-Oña has a Ph.D. in Management and a Degree in Industrial Engineering. She is Associate Professor in Innovation and Competitiveness in the School of Industrial Engineering at the Universidad Politécnica, Valencia (Spain). Her research interests include environmental proactivity and eco-innovation. E-mail: maseo@omp.upv.es. (Corresponding author)

\section{REFERENCES}

1. Amit, R. \& Zott, C. (2001). Value creation in e-business. Strategic management journal, 22(6-7), 493-520.

2. Dev, C. S., Winter, L., \& Mougeot Stroock, L. (2011). To Groupon or not to Groupon: A tour operator's 
dilemma. Cornell Hospitality Report, 11(19), http://www.hotelschool.cornell.edu/research/chr/pubs/reports/ abstract-15879.html.

3. Dholakia, U. M. (2010). How effective are Groupon promotions for businesses? Social Science Research Network. SSRN 1696327.

4. Kwok, L. \& Yu, B. (2013). Spreading social media messages on Facebook: An analysis of restaurant business-to-consumer communications. Cornell Hospitality Quarterly, 54(1), 84-94.

5. Lavidge, R. J. \& Steiner, G. A. (1961). A model for predictive measurements of advertising effectiveness. The Journal of Marketing, 59-62.

6. Lee, E. J. \& Jang, J. W. (2011). Not so imaginary interpersonal contact with public figures on social network sites: How affiliative tendency moderates its effects. Communication Research, 0093650211431579.

7. Lee, I. \& Lee, K. (2012). Social shopping promotions from a social merchant's perspective. Business Horizons, 55(5), 441-451.

8. Madera, J. M. (2012). Using social networking websites as a selection tool: The role of selection process fairness and job pursuit intentions. International Journal of Hospitality Management, 31(4), 1276-1282.

9. Mangold, W. G. \& Faulds, D. J. (2009). Social media: The new hybrid element of the promotion mix. Business horizons, 52(4), 357-365.

10. Needles, A. M. \& Thompson, G. M. (2013). Social media use in the restaurant industry: A work in progress. Cornell Hospitality Report, 13 (7), http://www.hotelschool.cornell.edu/research/chr/pubs/ reports/abstract-17223.html.

11. Pantelidis, I. S. (2010). Electronic meal experience: A content analysis of online restaurant comments. Cornell Hospitality Quarterly. 
NOTES 